\title{
O Escorbuto e a Vitamina C
}

\author{
$>\quad>$ \\ Marta Piñeiro Paulo Mendes \\ mpineiro@qui.uc.pt pjgm@uevora.pt
}

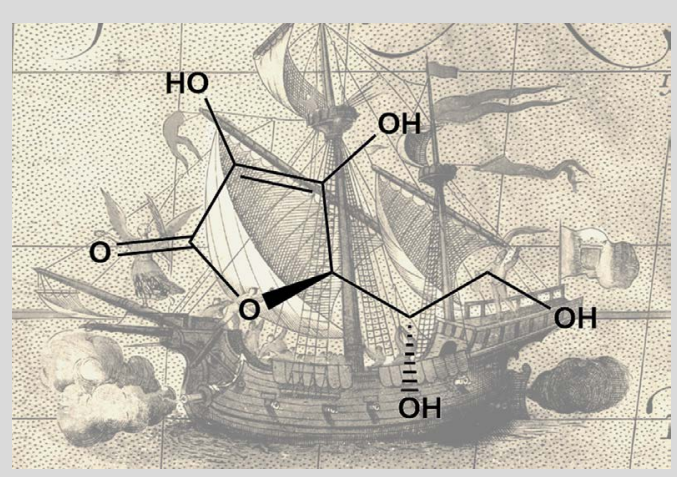

O nome ascórbico é derivado de "a" que significa "não, sem" e "scorbutus" (escorbuto ou scurvy em inglês), a doença causada pela sua deficiência. É uma molécula quiral que existe sob a forma de dois enantiómeros (só a forma $L$ possui atividade biológica).

0 ácido ascórbico tem capacidades antioxidantes sendo, portanto, um agente redutor. A sua capacidade antioxidante deriva da sua facilidade em oxidar-se, transformando-se em ácido desidroascórbico, por reação com oxigénio ou com espécies radicalares.

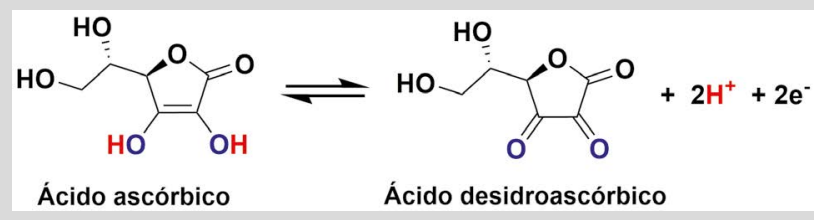

Devido à sua capacidade antioxidante, protege outras moléculas de serem oxidadas. Por exemplo, quando se adicionam algumas gotas de limão (rico em ácido ascórbico) a uma maçã acabada de cortar, diminui-se a velocidade do processo de oxidação das moléculas na superfície exposta da maçã, conseguindo-se retardar o seu escurecimento e manter o seu aspeto apetitoso durante mais tempo. São estas propriedades que fazem com que o ácido ascórbico tenha uma importância fundamental na indústria alimentar, sendo utilizado como conservante. É frequente encontrá-lo em muitos alimentos como aditivo (possui o código E300). Por exemplo, na página da Autoridade de Segurança Alimentar e Económica (ASAE) pode-se encontrar a seguinte informação: E300 - Ácido ascórbico (ou vitamina C): antioxidante em soluções aquosas e emulsões lipídicas, evita o escurecimento de frutos e sumos, preserva a cor da carne e utiliza-se como melhorante da farinha; ocorre naturalmente em muitos frutos e vegetais frescos, sendo também produzido comercialmente por síntese biológica ou química; é bem tolerado, não apresentando efeitos adversos em doses usuais, mas em doses altas pode provocar diarreia e erosão dentária; doses superiores a $10 \mathrm{~g}$ por dia levam à formação de pedras renais em pessoas suscetíveis. 
Como se observa, esta pequena molécula, cuja ausência tantos problemas provocou nas viagens marítimas, é essencial para a conservação dos alimentos e para a nossa saúde. Através do consumo de alimentos frescos e ricos nesta molécula, nomeadamente morangos, laranjas, frutos tropicais, bróculos, pimentos, cajús, salsa, espinafres, entre outros, estamos a contribuir para melhorar as condições da viagem que é a vida, que se quer longa. Mas sempre condimentada pela presença da Química...entre nós.

\section{Saiba mais em:}

Autoridade de Segurança Alimentar e Económica, Aditivos alimentares, asae.gov. $\mathrm{pt} / \mathrm{seguranca-alimentar/aditivos-alimentares/antioxidantes.aspx} \mathrm{(acedido} \mathrm{em}$ 11/06/2021).

Sapo Lifestyle, lifestyle.sapo.pt/saude/noticias-saude/artigos/500-anos-depoiso-escorbuto-esta-de-volta-a-culpa-e-das-dietas-pouco-variadas (acedido em $11 / 06 / 2021)$

Café com química, Química da Vitamina C, youtube.com/watch?v=cD6yRNujKoQ (acedido em 11/06/2021).

World of molecules, Vitamin CMolecule, worldofmolecules.com/antioxidants/ vitaminc.htm (acedido em 11/06/2021).

S. Murad D. Grove, K. A. Lindber G. Reynolds, A Sivarajah, S. R. Pinnell, Proc Natl. Acad. Sci. USA 1981, 78, 2879-2882. DOI: 10.1073/pnas.78.5.2879.

Luís de Camões, Os Lusíadas, Livraria Civilização Editora, Barcelos, 1999.

\section{À Procura das \\ Especiarias: o Cravinho}

\section{Marta Piñeiro}

mpineiro@qui.uc.pt

Conta a história que a luta pelo controlo do comércio de especiarias foi a grande motivação impulsionadora da viagem de circum-navegação de Fernão de MagaIhães. No século XV, o comércio das especiarias era dominado por mercadores de Génova e Veneza. As especiarias, vindas do Oriente pelo mar Mediterrâneo, eram vendidas a preço de ouro nas cidades europeias. Entre as mais importantes, destacavam-se a pimenta, a canela, o gengibre, a noz-moscada e o cravinho. Na época dos Descobrimentos, em particular com a descoberta do caminho marítimo para a Índia pelo navegador Vasco da Gama, Portugal consolidou o domínio das rotas comerciais. As especiarias, raras e caras, eram bens valiosos chegando a valer mais do que o ouro. A comercialização destes bens preciosos, entre outros, possibilitou o financiamento necessário a Portugal para a epopeia dos Descobrimentos.

Segundo L. F. F. R. Thomaz no seu livro O Drama de Magalhães e a Volta ao Mundo sem Querer, o cravinho, hoje comparado ao café (que, depois do petróleo, é a segunda mercadoria do comércio internacional), era das especiarias mais caras (mais do que a pimenta e o gengibre) no século XVI, sendo consumido na Pérsia, China e Índia. 0 cravinho, também conhecido por cravo-da-índia, é o botão floral seco de uma árvore (Syzygium aromaticum), originária das ilhas Molucas (atualmente parte da Indonésia), que pode atingir os 8 a 10 m de altura. Para além da sua utilização

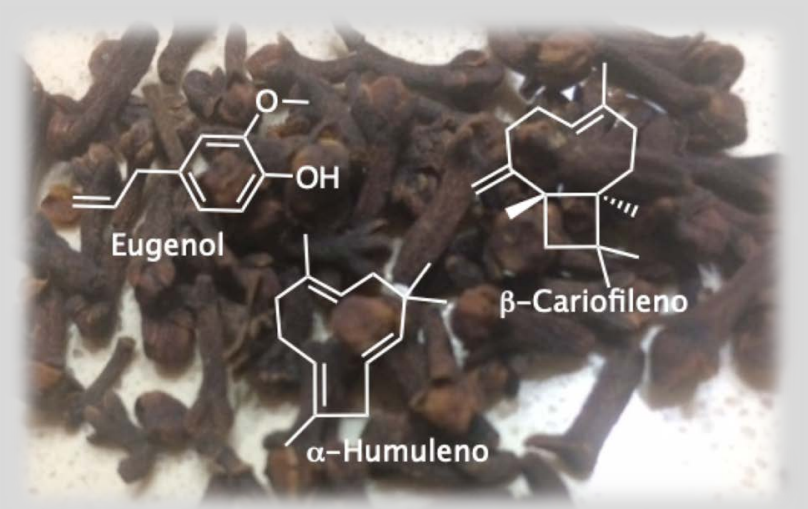

como tempero, o cravinho também era utilizado para evitar infestações de formigas, e o seu óleo tem diversas aplicações terapêuticas relacionadas com os seus diversos componentes.

A composição do óleo de cravinho, que pode ser obtido por destilação simples, por arraste de vapor ou por extração com solventes (também utilizando dióxido de carbono supercrítico, $\mathrm{scCO}_{2}$ ), depende da origem, da preparação e da forma de extração, mas apresenta sempre o mesmo componente principal, o eugenol (4-alil-2-metoxifenol), em proporções entre $70-90 \%$. É a este composto que se associa o aroma característico do cravinho e várias das suas propriedades terapêuticas. Dos botões secos extrai-se 15-20\% de óleo essencial, sendo a maior parte eugenol. Um quilograma de cravinho origina aproximadamente $150 \mathrm{~mL}$ de eugenol. $0 \beta$-cariofileno e o $\alpha$-humuleno são dois constituintes minoritários do cravinho. 0 primeiro é responsável pela atividade inseticida do 